\title{
Suomalainen pellonomistaja
}

\author{
Sami Myyrä ${ }^{1)}$, Eija Pouta ${ }^{1)}$ ja Harri Hänninen ${ }^{2)}$ \\ ${ }^{1)}$ MTT taloustutkimus, Luutnantintie 1300410 Helsinki, sami.myyra@mtt.fi, eija.pouta@mtt.fi \\ ${ }^{2)}$ Metsäntutkimuslaitos, Unioninkatu 40 A, 00170 Helsinki, harri.hanninen@metla.fi
}

\section{Tiivistelmä}

EU-aikana aktiivitilojen peltoalan kasvusta 2/3 on perustunut vuokraukseen ja vain kolmannes lisämaan ostoon. Suomen pelloista viljelläänkin nykyisin vuokrattuna jo noin 750000 hehtaaria eli kolmannes maan koko peltoalasta. Vuokraviljeltyjen peltojen kasvukunnon on todettu jääneen jälkeen omistajaviljelijöiden peltojen kasvukunnosta, mikä etenkin pitkällä aikavälillä vaarantaa maatalouden kehittämisen ja tuottavuuskasvun.

Tässä artikkelissa luodaan ensimmäistä kertaa kokonaiskuva suomalaisista pellonomistajista ja heidän pellon omistukseensa liittämistä tavoitteista. Tutkimusaineistoina käytettiin verottajan rekisteriaineistoa vuodelta 2004 ja postikyselyllä vuonna 2006 yhteensä 2684 omistajalta kerättyä aineistoa.

Tulosten perusteella pellonomistus sitoo lähes joka kymmenennen suomalaisen edelleen maatalouteen. Vaikka aktiivitilojen lukumäärä on laskenut alle 70000 tilaan, on pellonomistajia edelleen lähes puoli miljoonaa. Pelto-omaisuus on kuitenkin varsin keskittynyttä, sillä noin viidesosa omistajista omisti yli 60 \% peltoalasta. Suurten ikäluokkien ikääntyminen on selkein omistusrakenteen muutokseen tulevaisuudessa vaikuttava tekijä. Iäkkäiden pellonomistajien määrä on suuri, mutta heidän omistamansa peltoala on suhteessa pienempi kuin nuorten. Pellonomistajat ovat maantieteellisesti sangen kiinteästi yhteydessä tilaansa, sillä lähes kolme neljäsosaa omistajista asuu tilan sijaintipaikkakunnalla. Suurin osa pellonomistajista ei saa maataloustuloa ja noin neljäsosa pellosta on sellaisten pellonomistajien omistuksessa, jotka eivät harjoita kaupallista maataloustuotteiden tuotantoa eivätkä pellon vuokrausta.

Pellonomistajat jakautuivat viiteen ryhmään pelto-omaisuuteensa kohdistuvien tavoitteiden suhteen. Ensimmäinen ryhmä nimettiin maataloustuloja painottaviksi (18\% omistajista). Heillä tulon saantiin liittyvät tavoitteet olivat luonnollisesti tärkeimpiä, mutta myös tunne- ja perinnetavoitteet sekä virkistys- ja luontotavoitteet painottuivat. Harrastusviljelijöillä (21\%) korostuivat harrastus- ja kotitarveviljelyyn liittyvät tavoitteet, mutta myös sijoittamiseen ja taloudelliseen turvallisuuteen sekä tulonsaantiin liittyvät tavoitteet korostuivat heillä. Taloudellista turvaa korostaville (21\%) keskeisimpiä olivat taloudelliseen turvallisuuteen ja sijoittamiseen liittyvät tavoitteet tunne- ja perinnetavoitteiden ohella. Aineetonta arvostavilla (23\%) korostuivat tunne- ja perinnetavoitteet sekä virkistys- ja luontotavoitteet. Välinpitämättömillä (18 \%) mitkään tavoitteista eivät nousseet tärkeiksi.

Omistajien tavoitteilla näyttää olevan vaikutusta omistajien käyttäytymiseen ja maanhallintapäätöksiin. Useimmin pelto oli omistajien omassa viljelyssä maataloustuloja painottavilla, joilla peltoalasta neljä viidesosaa oli vuonna 2006 itsellä viljelyssä. Myös harrastusviljelijöillä pelloista valtaosa oli omassa viljelyssä. Yleisintä pellon poisvuokraus oli taloudellista turvaa korostavilla ja aineetonta arvostavilla, joilla noin puolet peltoalasta oli luovutettu vuokraviljelijälle. Kaikkiaan pellonomistajat jättivät noin 12 \% peltoalasta viljelemättä.

Tulokset pohjustavat pellonvuokrausta säätelevien ja kauppaa vauhdittavien politiikkatoimien arviointia ja suunnittelua sekä monipuolistavat aiheesta käytävää kansalaiskeskustelua.

Asiasanat: pellonomistajat, omistusrakenne, omistuksen tavoitteet, maankäyttöpäätökset, maanhallintapäätökset, pellonvuokraus, pellonomistus, myyntihalukkuus 


\section{Johdanto}

Suomalainen pellonomistajakunta on jakautunut maatalouden rakennemuutoksen aktiiviviljelijöihin ja tuotannosta luopuneisiin maanomistajiin. Tuotannosta luopuvat pellonomistajat ovat tyypillisesti säilyttäneet omistuksensa ja pelto on vuokrattu aktiiviviljelijöille. Tämä onkin mahdollistanut maatalouden nopean rakennekehityksen. Vuokraviljelyyn liittyy myös ongelmia, sillä epävarmuus pellonhallinnasta alentaa viljelijöiden halukkuutta peltojen kasvukunnon ylläpitoon (Myyrä ym. 2005). Vuokrapeltojen hallintaoikeuteen liittyvä epävarmuus on näin huomattava kustannus paitsi yksittäiselle vuokraviljelijälle ja maan omistajalle myös koko yhteiskunnalle.

Pellonomistusrakenne vaikuttaa elintarvikkeiden tuotantoon ja tarjontaan sekä maatalouden tuottamiin myönteisiin ja kielteisiin ulkoisvaikutuksiin ja on siten vahvasti kytköksissä maatalouspolitiikkaan. Maatalouspolitiikan suunnittelussa pellonomistajien ja heidän tavoitteidensa tuntemus on rinnastettavissa aktiiviviljelijöiden rakenteen ja tavoitteiden tuntemukseen, sillä maa ja työ ovat keskeisiä tuotannontekijöitä maataloudessa.

Aikaisemmat tiedot pellonomistajista perustuvat aktiiviviljelijöihin. Tässä artikkelissa kuvataan koko pellonomistajakunnan rakenne. Pellonomistajat ryhmitellään aluksi heidän omistukselleen asettamien tavoitteidensa suhteen ja seuraavaksi tarkastellaan, millaisia pellonkäyttövalintoja, esimerkiksi vuokraus tai myynti, tavoitteiltaan erilaiset omistajat ovat tehneet ja aikovat tehdä. Tulokset perustuvat Myyrän ym. (2007) valmisteilla olevaan tutkimukseen.

\section{Aineisto ja menetelmät}

Tutkimuksessa käytettiin sekä rekisteriaineistoja että postikyselyaineistoa. Ainoa aineisto, josta voitiin saada omistajatiedot aktiiviviljelyn ulkopuolella olevista pellonomistajista, oli verohallituksen maatilarekisteri. Tähän rekisteriaineistoon kuuluivat kaikki maatalousmaanomistajat (yksityishenkilöt ja juridiset henkilöt). Maatilarekisterissä maatalousmaa jaetaan kolmeen luokkaan: peltoon, puutarhaan sekä niittyyn ja laitumeen. Koska valtaosa tästä maatalousmaasta (95\%) on peltoa, puhutaan tutkimuksessa pellonomistajista. Rekisteriaineisto kohdistui vuoteen 2004. Aineistoon haluttiin sisällyttää pellonomistajat mahdollisimman laajasti. Myös pienten peltoalojen mukaan ottamista pidettiin tärkeänä, koska niiden omistajilla on taloudellinen side maaseudulle ja pienetkin peltoalat voivat olla keskeisiä maaseutumaisemassa. Pieniin tiloihin kohdistuu kiinnostusta myös vapaa-ajan asuntoina ja maallemuuton kohteina. Toisaalta pienet, pirstaleiset peltoalat ovat erityisen alttiita poistumaan maataloustuotannosta, eikä niitä senkään vuoksi haluttu jättää aineiston ulkopuolelle.

Postikyselyn perusjoukkona oli Suomessa vähintään yhden hehtaarin maatalousmaata omistavat henkilöt. Otantakehikkona käytettiin verohallituksen maatilarekisteriä. Tällaisia tiloja aineistossa oli 300 986. Tiloista tiedettiin omistajatietojen lisäksi mm. peltopinta-ala ja sijaintikunta. Näiden tietojen perusteella aineisto ositettiin sekä maatalouden suuraluejaon että pinta-alojen perustella neljään luokkaan. Ensin poimittiin 6080 tilan otos. Valinta tehtiin yksinkertaisella satunnaisotannalla ilman takaisinpanoa, jolloin jokaisessa ositteessa kullakin tilalla oli yhtä suuri valintatodennäköisyys. Tämän jälkeen erotettiin yhtymät ja tavalliset tilat erilleen. Yhtymille poimittiin osakkaista yksi vastaaja. Tavallisille tiloille vastaajaksi valittiin arpomalla joko varsinainen omistaja tai puoliso, mikäli tilalta oli puolison tiedot olemassa. Koska veroaineistossa oli varsin yksityiskohtaiset tiedot omistajista, voitiin kyselyaineistoon vastanneita verrata siihen, ja painottaa kyselyaineisto vastaamaan perusjoukkoa.

Postikyselyssä kartoitettiin erityisesti pellonomistajan tavoitteita sekä pellon vuokraukseen ja myyntiin liittyviä käsityksiä ja aikomuksia. Omistajan tavoitteita mitattiin kysymysväittämillä, jotka oli laajennettu ja sovitettu metsänomistajatutkimuksista vakiintuneista tavoiteväittämistä (esim. Karppinen ym. 2002). Kysymyslomakkeella vastaajaa pyydettiin arvioimaan kaikkiaan 28 tavoitteen tärkeyttä. Tavoiteväittämät liittyivät, virkistykseen ja vapaa-aikaan, maataloustuotantoon ja tuloon, peltoluontoon ja maisemaan, taloudelliseen turvallisuuteen, pellon tunnearvoihin sekä sijoittamiseen. Pellon hallintaan ja käyttöön liittyvillä kysymyksillä kartoitettiin nykyistä peltojen käyttöä vaihtoehtoina peltojen viljely, hoitaminen viljelemättä, myyminen, antaminen vuokralle, jättäminen viljelemättä ja metsitys. Nykyisen käytön mittaamisen lisäksi vastaajaa pyydettiin arvioimaan, kuinka tilan peltoja käytettäisiin viiden vuoden kuluttua.

Postikyselyn tavoiteväittämät tiivistettiin pääkomponenttimenetelmällä viiteen tavoiteulottuvuu- 
teen, jotka tulkittiin alkuperäisten muuttujien saamien latausten perustella. Tavoiteulottuvuudet kuvasivat 1) tunne- ja perinnetavoitteita, 2) ulkoilu ja luontotavoitteita, 3) tulonsaantiin liittyviä tavoitteita, 4) sijoittamiseen ja taloudelliseen turvallisuuteen liittyviä tavoitteita ja 5) harrastus- ja kotitarveviljelyyn sekä metsästykseen liittyviä tavoitteita. Näiden perusteella pellonomistajat luokiteltiin viiteen tavoitteiltaan erilaiseen ryhmään (K-means cluster). Ryhmittelyanalyysi perustui tavoiteulottuvuuksien havaintokohtaisiin pääkomponenttipisteisiin. Ryhmien lukumäärä ratkaistiin ryhmien luontevuuden ja tulkinnallisen kiinnostavuuden perusteella. Ryhmät erottuivat tilastollisesti merkitsevästi toisistaan.

\section{Tulokset ja tulosten tarkastelu}

\section{Omistajien kokonaismäärä ja omistusmuodot}

Vuonna 2004 Suomessa oli kaikkiaan 487010 pellonomistajaa. Valtaosa pellonomistajista oli yksityishenkilöitä (426 402 omistajaa). Varsinaisia omistajia heistä oli 287657 ja omistajien puolisoita 138745 (Taulukko 1). Yksityishenkilöt omistivat yksin, yhdessä puolison kanssa tai kuolinpesän kautta 97 \% peltopinta-alasta. Peltoa omistaneita kuolinpesiä oli yhteensä 45325 kappaletta. Kuolinpesien omistuksessa oli vuonna 2004 yhteensä 234000 ha peltoa, mikä on 9 \% koko peltoalasta. Tämä on hieman vähemmän kuin perikuntien kautta toteutuva yksityismetsien omistus, joka on $12 \%$ yksityismetsien alasta (Karppinen ym. 2002). Suurimmasta osasta kuolinpesiä osakkaista ei ollut tarkempia tietoja. Osasta kuolinpesiä tiedettiin kuitenkin jäsenten lukumäärä, joka oli keskimäärin 2,7 omistajaa.

Taulukko 1. Pellonomistajien määrä ja peltoala omistusmuodoittain vuonna 2004.

\begin{tabular}{|c|c|c|c|c|c|}
\hline Omistusmuoto & & $\begin{array}{l}\text { Omistajia } \\
\text { henkilöä }\end{array}$ & $\%$ omistajista & Hehtaaria & $\%$ pellosta \\
\hline \multirow[t]{4}{*}{ Yksityishenkilöt } & \multirow{2}{*}{$\begin{array}{l}\text { Varsinainen omistaja } \\
\text { Puoliso }\end{array}$} & 287657 & 60,5 & 1625912 & 61,6 \\
\hline & & 138745 & 29,2 & 703311 & 26,7 \\
\hline & Kuolinpesän edustaja & 45325 & 9,5 & 234094 & 8,9 \\
\hline & Yhteensä & 471727 & 99,2 & 2563317 & 97,1 \\
\hline $\begin{array}{l}\text { Institutionaaliset } \\
\text { omistajat }\end{array}$ & Yhteensä & 3711 & 0,8 & 75843 & 2,9 \\
\hline Kaikki & Yhteensä & 475438 & 100 & 2639160 & 100 \\
\hline
\end{tabular}

\section{Omistajien taustapiirteet}

Pellon omistajista $55 \%$ oli miehiä ja he omistivat 60 \% peltoalasta. Pellonomistajien keski-ikä oli 58 vuotta, joten tässä suhteessa he vastaavat metsänomistajia (Karppinen ym. 2002). Kuten metsänomistajatutkimuksessa on havaittu, myös pellonomistajissa naisten keski-ikä oli korkeampi kuin miesten. Alle 40vuotiaiden pellonomistajien osuus oli noin $17 \%$ (Taulukko 2). Pellonomistajissa nuorten osuus oli selvästi suurempi kuin metsänomistajissa, mikä liittyy maatalouden sukupolvenvaihdoskäytäntöihin. Alle 40 vuoden ikäiset pellonomistajat omistivat myös suuremman osuuden pellosta (22 \%) kuin saman ikäiset metsänomistajat yksityismetsien pinta-alasta (13\%). 40-59-vuotiaita pellonomistajia oli $42 \%$ kaikista omistajista ja yli 60 -vuotiaita $41 \%$. Yli 60-vuotiaat omistivat osuuttaan pienemmän osan peltopinta-alasta, 30 $\%$.

Ammattiasemaltaan suurin pellonomistajaryhmä olivat eläkeläiset, joita oli noin 36 \%. Eläkeläisomistajien keskuudessa tyypillistä oli perusasteen koulutus, sijainti keskimääräistä useammin Itä- tai Pohjois-Suomessa ja keskimääräistä pienempi peltoala. Pääsääntöisesti pellot eivät tuottaneet tuloa tai tulo saatiin peltojen vuokrauksesta. Noin kolmasosa (35\%) pellonomistajista oli palkansaajia. Palkansaajapellonomistajat olivat tyypillisesti muita omistajaryhmiä korkeammin koulutettuja ja tilan sijaintikunnan ulkopuolella suuremmissa kunnissa asuvia henkilöitä. Heidän peltonsa olivat keskimääräistä pienempiä ja tuottivat vuokratuloa omistajalleen. Maa- tai metsätalousyrittäjiksi itsensä luokitteli noin $19 \%$ omistajista. Maa- ja metsätalousyrittäjien taustatekijät olivat aktiiviviljelijöistä muodostuneen yleisen kuvan mukaisia. He olivat tyypillisesti nuorempia tai keski-ikäisiä ja asuivat keskimääräistä useammin tilallaan. Tilan peltopinta-ala oli tyypillisesti yli 15 hehtaaria ja tuotti omistajalleen viljelytuloa. 
Taulukko 2. Pellonomistajien lukumäärä ja peltoala eri omistajaryhmissä.

\begin{tabular}{|c|c|c|c|c|c|}
\hline & & Omistajia & $\begin{array}{r}\% \\
\text { omistajista }\end{array}$ & ha & $\begin{array}{c}\% \\
\text { ha }\end{array}$ \\
\hline \multirow[t]{2}{*}{ Sukupuoli } & Mies & 253368 & 55 & 1497648 & 60 \\
\hline & Nainen & 204478 & 45 & 998158 & 40 \\
\hline \multirow[t]{3}{*}{ Ikä } & Alle 40 vuotta & 83362 & 17 & 578630 & 22 \\
\hline & 40-59 vuotta & 206032 & 42 & 1263515 & 48 \\
\hline & 60 ja yli & 197616 & 41 & 797015 & 30 \\
\hline \multirow[t]{5}{*}{ Ammattiasema } & Palkansaaja & 168505 & 35 & 625481 & 24 \\
\hline & Maa- tai metsätalousyrittäjä & 91558 & 19 & 1261518 & 48 \\
\hline & Muu itsenäinen yrittäjä & 32630 & 7 & 153071 & 6 \\
\hline & Eläkeläinen & 174350 & 36 & 541028 & 21 \\
\hline & $\begin{array}{l}\text { Muи (työtön, opiskelija, } \\
\text { kotirouva) }\end{array}$ & 19967 & 4 & 58062 & 2 \\
\hline \multirow[t]{5}{*}{ Tavoiteryhmät } & Maataloustuloja painottavat & 86688 & 18 & 1087334 & 41 \\
\hline & Harrastusviljelijät & 102759 & 21 & 662429 & 25 \\
\hline & Taloudellista turvaa korostavat & 101785 & 21 & 395874 & 15 \\
\hline & Aineetonta arvostavat & 109577 & 23 & 287668 & 11 \\
\hline & Välinpitämättömät & 87175 & 18 & 205854 & 8 \\
\hline \multirow[t]{2}{*}{ Asuinkunta } & Tilan sijaintikunta & 347233 & 71 & 2277773 & 86 \\
\hline & Ei tilan sijaintikunta & 139777 & 29 & 361387 & 14 \\
\hline \multirow[t]{5}{*}{ Peltoala } & alle 1 ha & 109910 & 23 & 25169 & 1 \\
\hline & $1-3$ ha & 103150 & 22 & 122463 & 5 \\
\hline & 3-7 ha & 93450 & 19 & 289953 & 11 \\
\hline & $7-15$ ha & 89854 & 19 & 580577 & 22 \\
\hline & yli 15 ha & 90646 & 19 & 1620999 & 61 \\
\hline \multirow[t]{4}{*}{ Maatalouden tulot } & ei tuloa & 259169 & 54 & 628863 & 24 \\
\hline & vuokratuloa & 96430 & 20 & 505419 & 19 \\
\hline & tuloa viljelystä & 109271 & 23 & 1370185 & 53 \\
\hline & vain tukea & 18895 & 4 & 103452 & 4 \\
\hline \multirow{4}{*}{$\begin{array}{l}\text { Maatalouden } \\
\text { ulkopuoliset tulot }\end{array}$} & Alle $15000 €$ & 145480 & 30 & 688002 & 27 \\
\hline & $15000-30000 €$ & 143186 & 29 & 674888 & 26 \\
\hline & $30000-45000 €$ & 95911 & 20 & 507236 & 20 \\
\hline & Yli $45000 €$ & 104544 & 21 & 729344 & 28 \\
\hline Kaikki & & 487010 & & 2639160 & \\
\hline
\end{tabular}

Kursiivilla merkityt tiedot perustuvat kyselyaineistoon vuodelta 2006. Muut tiedot ovat rekisteriaineistosta vuodelta 2004.

\section{Pellonomistajien tavoitteet}

Pellonomistajat jakautuivat melko tasan sen suhteen, millaisia tavoitteita he asettivat pellonomistukselleen. Maataloustuloja painottavia ja välinpitämättömiä oli hieman muita ryhmiä vähemmän eli noin 18 prosenttia. Reilu viidesosa omistajista luettiin harrastusviljelijöiksi ja lähes yhtä suuri osa taloudellista turvaa korostaviksi. Suurin omistajaryhmä, lähes $23 \%$ omistajista, oli omistamisen aineettomia tavoitteita arvostavat (Kuva 1).

Vaikka maataloustuloja painottavia omistajia oli alle viidesosa kaikista omistajista, omistivat he noin 45 \% peltopinta-alasta. Myös harrastusviljelijöiden omistusosuus, noin neljäsosa peltoalasta, oli heidän suhteellista osuuttaan suurempi. Muissa tavoiteryhmissä omistusosuus jäi selvästi ryhmän suhteellista osuutta pienemmäksi. 


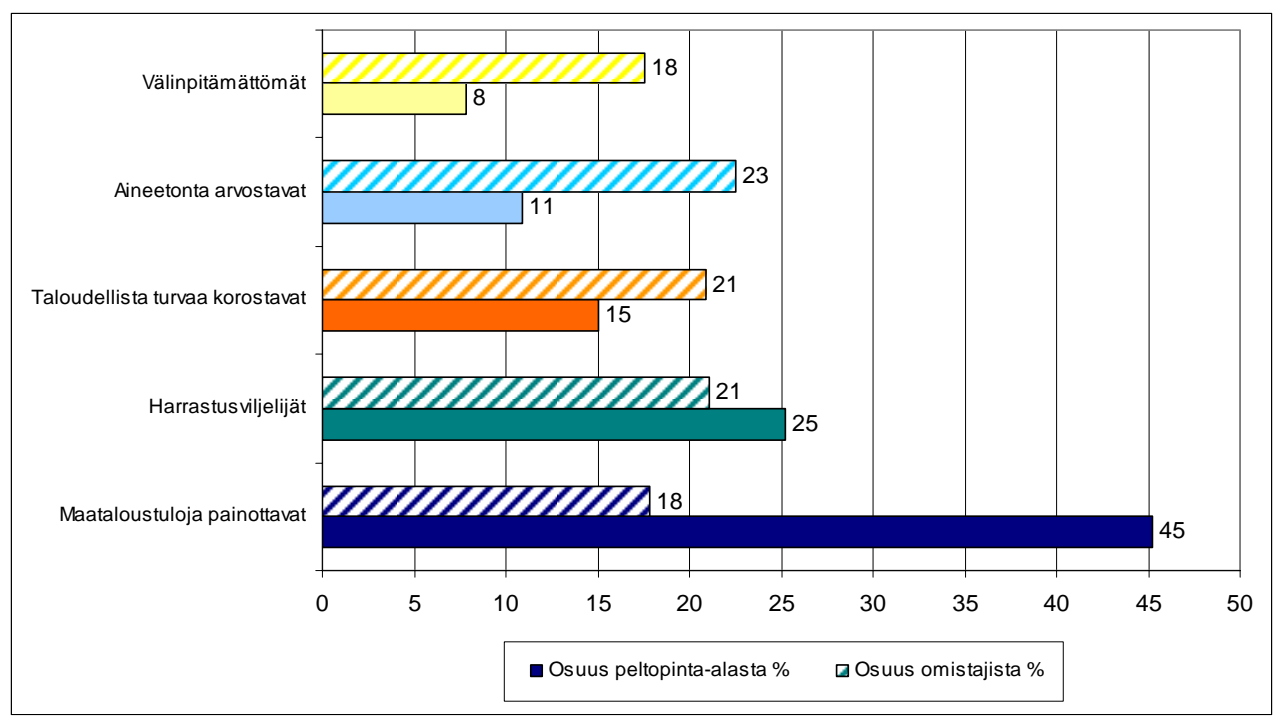

Kuva 1. Pellon omistajien lukumäärä- ja peltoalaosuudet tavoiteryhmittäin vuonna 2006.

Tiedot pellonomistajaryhmien sosioekonomisesta taustasta ja tilan ominaisuuksista mahdollistavat tavoiteryhmien profiloinnin. Tavoiteryhmät poikkesivat kaikkien keskeisten taustamuuttujien osalta merkitsevästi toisistaan. Maataloustuloja painottavien omistajien profiili oli melko ilmeinen: maa- tai metsätalousyrittäjyys, pienet asuinkunnat, tilan sijainti Etelä-Suomessa ja runsas peltopinta-ala. Harrastusviljelijöihin kuuluminen liittyi myös keskimääräistä useammin maa- tai metsätalousyrittäjyyteen, ilmeisesti lähinnä metsätalousyrittäjyyteen, sillä metsätulojen osuus tilan liikevaihdosta oli keskimääräistä suurempi. Harrastusviljelijät asuivat pienissä kunnissa ja omistivat peltoa keskimääräistä enemmän. He olivat asenteiltaan tyytyväisiä tilan sijaintikuntaan ja henkisesti vahvasti sidoksissa siihen.

Taloudellista turvaa korostaville, aineetonta arvostaville ja välinpitämättömille oli yhteistä asuminen keskimääräistä useammin suuressa kunnassa ja muu sosioekonominen asema kuin maa- tai metsätalousyrittäjyys. Sen sijaan omistajan asenteet tilan sijaintikuntaa kohtaa erottelivat ryhmiin kuuluvia. Taloudellista turvaa korostavilla oli myönteinen asenne tilan sijaintikuntaa kohtaan toisin kuin aineetonta arvostavilla ja välinpitämättömillä. Välinpitämättömien henkiset siteet tilan sijaintipaikkakunnalle olivat lisäksi muita vähäisemmät. Ryhmät erosivat myös tilojen ominaisuuksien suhteen. Taloudellista turvaa korostavilla peltopinta-ala oli melko keskimääräinen ja tilat painottuivat Länsi-Suomeen. Aineetonta arvostavilla metsätalouden osuus tilan tuloista oli keskimääräistä suurempi, tilat sijaitsivat useammin Itä-Suomessa ja peltoalat olivat pieniä. Välinpitämättömät omistivat puolestaan keskimääräistä useammin pienen peltotilan Pohjois-Suomessa.

\section{Pellon nykyinen ja tuleva käyttö}

Vuonna 2006 peltopinta-alasta 58 \% oli omistajan omassa viljelyssä. Omistajien pellon käyttöä koskevien aikomusten perustella on arvioitavissa, että alle puolet peltoalasta on omistajan viljelyksessä vuonna 2011 (Kuva 2). Omistajan oma viljely säilyy kuitenkin tyypillisimpänä pellonkäyttömuotona riippumatta sukupolvenvaihdosten myötä tulevista uusista pellonomistajista.

Tiukimmin pelto oli omistajien viljelyssä maataloustuloja painottavien tavoiteryhmässä. Tässä ryhmässä neljä viidesosaa peltoalasta oli vuonna 2006 omistajan omassa viljelyssä. Vuonna 2011 viljelyssä oleva ala on kuitenkin yli viidesosan pienempi, eli $58 \%$. Suurin osa poistuvasta alasta kohdistuu sukupolvenvaihdoksiin. Muita maataloustuloja painottavien ryhmässä yleistyviä pellonkäyttömuotoja olivat pois vuokraaminen ja myyminen, mutta merkittävälle osalle (7 \%) peltoalaa ei ollut vielä tiedossa käyttötarkoitusta.

Myöskään harrastusviljelijöiden ryhmässä pellon tulevasta käytöstä ei ollut täyttä varmuutta. Joka seitsemännellä harrastusviljelijöistä peltojen tuleva käyttö oli epäselvää. Heillä $11 \%$ peltoalasta oli vuonna 2006 sukupolvenvaihdosmenettelyssä. Harrastusviljelijät eivät nähneet lähitulevaisuudessa suuria muutoksia pellon pois vuokrauksessa tai viljelemättä hoitamisessa, sillä näiden käyttömuotojen suhteelliset osuudet säilyivät vuoden 2006 tasolla. Myyntiin harrastusviljelijät arvioivat laittavansa kuitenkin vain yhden prosentin peltoalastaan vuoteen 2011 mennessä, mikä oli muihin verrattuna selvästi vähiten. 
Taloudellista turvaa korostavien tavoiteryhmään kuuluvien pellonomistajien pelloista lähes puolet (48 \%) oli vuokrattu pois vuonna 2006 ja omassa viljelyssä oli noin kolmasosa. Taloudellista turvaa korostavien omistamasta peltoalasta lähes neljänneksen arvioitiin vaihtavan omistajaa vuoteen 2011 mennessä. Kaksi kolmasosaa omistajan vaihdoksista tapahtuu sukupolvenvaihdoksien kautta ja kolmasosa kaupoilla. Pellon vuokrauksen pinta-alamuutokset riippuvat tässä ryhmässä lähinnä uusien omistajien maankäyttöpäätöksistä.

Aineetonta arvostavien tavoiteryhmä oli ainoa ryhmä, jossa pellon viljelemättä hoitaminen näytti lisääntyvän, kuten myös peltojen metsittäminen. Tavoitteiden ja pellonkäyttöpäätösten yhteys oli siis ainakin jossain määrin havaittavissa.

Sukupolvenvaihdoksin omistajaa vaihtavan peltoalan osuus oli pienin välinpitämättömien tavoiteryhmässä. Toisaalta viljelemättä ja hoitamatta jättäminen, metsittäminen ja myyminen olivat yleisempiä pellonkäyttömuotoja tässä tavoiteryhmässä kuin muiden pellonomistajien keskuudessa.

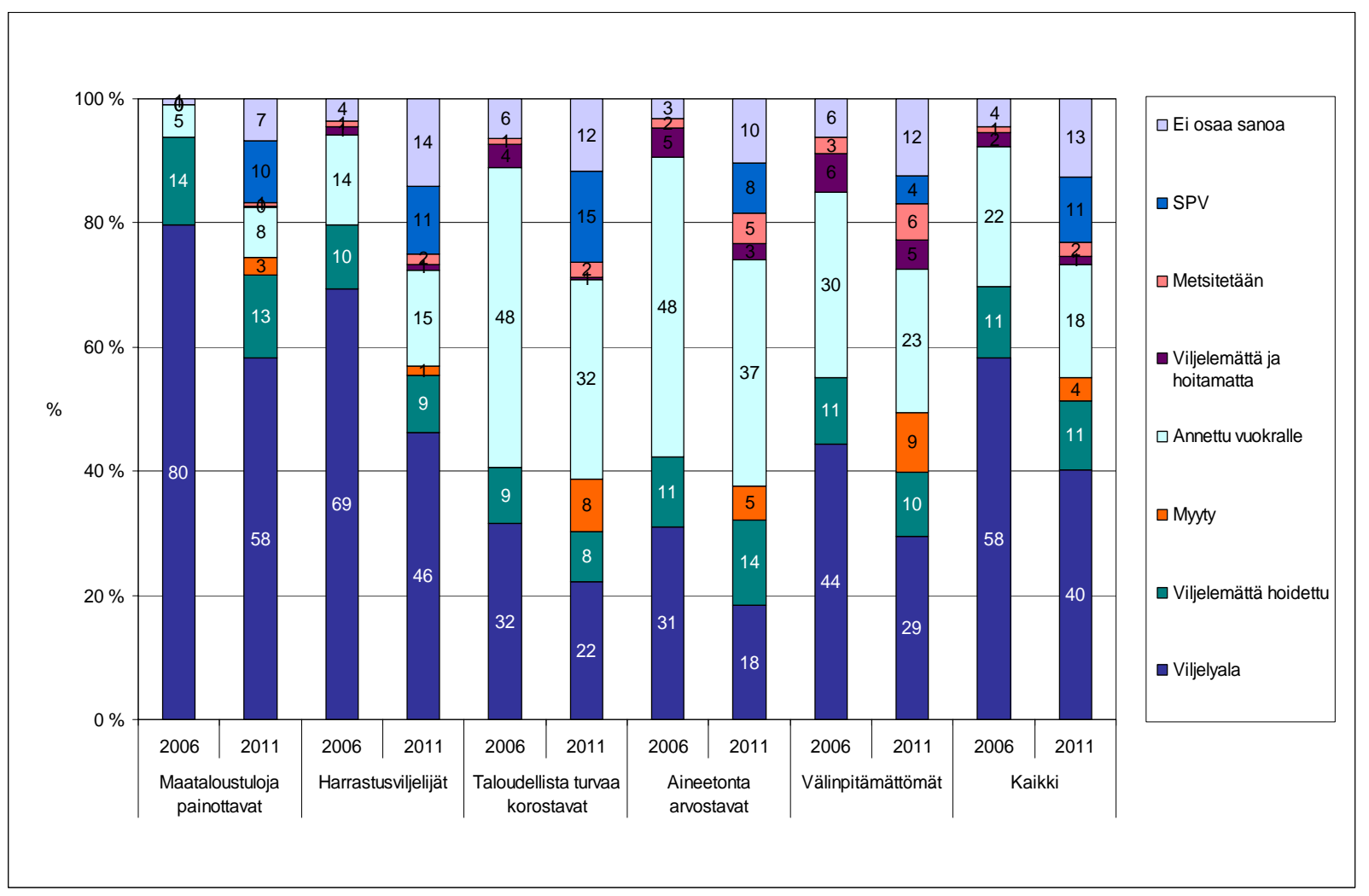

Kuva 2. Tavoiteryhmiin kuuluvien pellonomistajien pellon käyttö vuonna 2006 ja aikomukset pellon käytöstä vuonna 2011 (\% peltoalasta).

\section{Johtopäätökset}

Suurin osa pellonomistajista ei saanut vuonna 2006 lainkaan maataloustuloja, ja noin neljäsosa pelloista oli sellaisten omistajien omistuksessa, jotka eivät harjoittaneet kaupallista maataloustuotteiden tuotantoa tai pellon vuokrausta. Vain puolet peltoalasta oli maataloustuotteiden myynnistä tuloa saavien viljelijöiden omistuksessa. Viidesosa omistajista sai maistaan vain vuokratuloa ja heidän hallussaan oli puoli miljoonaa hehtaaria peltoa.

Pellonomistajien tavoitteet kertovat omistajien monimuotoisuudesta. Alle viidesosalle omistajista pelto oli tärkeä nimenomaan maataloustulon lähteenä. Muut kuin tulonsaantiin liittyvät tavoitteet osoittautuivat suurelle osalle omistajista hyvin tärkeiksi. Erityisesti merkityksellisiä ovat omistamiseen liittyvät tunne- ja perinnetavoitteet sekä vapaa-ajan viettoon ja luontoon ja maisemaan liittyvät tavoitteet.

Pellonomistajat ryhmittyivät omistukselle asettamiensa tavoitteiden suhteen viiteen melko yhtä suureen ryhmään. Ryhmistä kaksi liittyi erityisesti aktiiviseen maatalouteen: maataloustuloa painottavat ja harrastusviljelijät. Kolmen muutan ryhmän - taloudellista turvaa korostavat, aineetonta arvostavat ja välinpitämättömät - kohdalla korostuivat tilan ulkopuolella asuminen ja tilan ulkopuolinen ansiotyö tai eläk- 
keellä oleminen. Tavoiteryhmään kuulumista selitti erityisesti tilan pellon määrä ja maantieteellinen sijainti (suuralue).

Tavoitteet näyttävät liittyvän hyvin kiinteästi pellon käyttöön. Maataloustuloja painottavilla pellot olivat useimmin viljeltyjä; peräti neljä viidesosaa peltoalasta viljeli omistaja itse vuonna 2006. Myös harrastusviljelijöiden pelloista valtaosa oli omassa viljelyssä, ja vain joka seitsemäs peltohehtaari oli vuokrattu pois. Yleisintä pellon poisvuokraus oli taloudellista turvaa korostavilla ja aineetonta arvostavilla, joilla noin puolet peltoalasta oli luovutettu vuokraviljelijälle.

Halukkuus myydä peltoa osoittautui vaatimattomaksi. Viiden vuoden kuluessa vain muutama prosentti omistajista arvioi myyvänsä peltoa. Myyntihalukkuus oli suurinta välinpitämättömien ja taloudellista turvaa korostavien omistajien keskuudessa.

Tutkimus tarjoaa ensimmäistä kertaa kokonaiskuvan suomalaisista pellonomistajista, myös maataan viljelemättömistä omistajista. Passiivisten omistajien tavoitteet kuvastavat hyvin monitahoisia peltoon liittyviä arvoja. Näitä monitahoisia arvoja ilmentää 260000 pellonomistajaa, jotka haluavat säilyttää maatalousmaan omistuksensa, vaikka eivät saisi siitä lainkaan tuloja. Kuitenkin tuotantoon tai hintaan perustuva käsitys pellon arvosta ohjaa usein maatalouspoliittista keskustelua. Tutkimus antaakin uudenlaisen pohjan arvioida pellonomistajiin vaikuttavia politiikkatoimia.

\section{Kirjallisuus}

Karppinen, H., Hänninen, H. ja Ripatti, P. 2002. Suomalainen metsänomistaja 2000. Metsäntutkimuslaitoksen tiedonantoja $852.83 \mathrm{~s}$.

Myyrä, S. Pouta, E. ja Hänninen H. 2007. Suomalainen pellonomistaja. Käsikirjoitus sarjaan Maa- ja elintarviketalous, Talous.

Myyrä, S., Ketoja, E., Yli-halla, M. ja Pietola, K. 2005. Land improvements under land tenure insecurity : the case of pH and phosphate in Finland. Land economics 81, 4: 557-569. 